\title{
Peningkatan Pengetahuan Kanker Payudara dan Ketrampilan Periksa Payudara Sendiri (SADARI) untuk Deteksi Dini Kanker Payudara di Semutan Jatimulyo Dlingo
}

\author{
Erlina Marfianti* \\ Departemen Ilmu Penyakit Dalam, Fakultas Kedokteran Universitas Islam Indonesia \\ *Corresponding Email: erlina.marfianti@uii.ac.id
}

\begin{abstract}
ABSTRAK
Kanker payudara merupakan penyebab kematian tertinggi kanker pada perempuan di Indonesia. Hal ini disebabkan penderita kanker payudara pergi ke pelayanan kesehatan saat kanker payudara sudah stadium lanjut. Keterlambatan penanganan ini disebabkan kurangnya pengetahuan masyarakat tentang kanker payudara dan belum tahunya cara periksa payudara sendiri (SADARI) untuk deteksi dini kanker payudara. Penanganan kanker payudara sejak stadium dini diharapkan dapat mengurangi angka kematian dan meningkatkan angka harapan hidup. Pengetahuan kanker payudara dan SADARI di mayoritas masyarakat terutama ibu ibu Semutan Jatimulyo Dlingo masih rendah dan banyak yang belum tahu cara deteksi dini dengan SADARI. Berdasarkan kondisi tersebut, kegiatan pengabdian masyarakat ini bertujuan untuk meningkatkan pengetahuan kanker payudara dan meningkatkan ketrampilan SADARI pada masyarakat Semutan Jatimulyo Dlingo. Kegiatan yang dilakukan adalah pemberian edukasi dengan pemaparan materi dan diskusi, pelatihan ketrampilan SADARI dengan manikin, pelatihan praktek mandiri terbimbing dengan manikin. Tingkat pengetahuan diukur dengan tes sebelum dan sesudah rangkaian seluruh kegiatan. Analisis hasil tes didapatkan hasil terdapat peningkatan pengetahuan setelah edukasi dan pelatihan SADARI dibanding sebelumnya. Kesimpulannya terdapat peningkatan pengetahuan tentang kanker payudara dan ketrampilan SADARI pada masyarakat di Semutan Jatimulyo Dlingo setelah pemberian edukasi dan pelatihan.
\end{abstract}

Kata Kunci: Deteksi dini, Kanker Payudara, Pengetahuan, Periksa Payudara Sendiri (SADARI)

\section{ABSTRACT}

Breast cancer is the leading cause of cancer death in Indonesian women. Breast cancer sufferers come to health services when breast cancer is in an advanced stage. This delay is due to the lack of public knowledge about breast cancer and early detection of breast self-examination (BSE). Treating breast cancer from an early stage can reduce mortality. Knowledge of breast cancer and BSE in the Semutan Jatimulyo Dlingo community is still low and they don't know how to detect it early with BSE. This community service activity aims to increase breast cancer knowledge and BSE skills in the Semutan Jatimulyo Dlingo community. The activities carried out are providing education with material presentation and discussion, BSE skills training with mannequins, guided self-practice training. The level of knowledge was measured by tests before and after the activity. Analysis of the test results showed that there was an increase in knowledge after BSE education and training. The conclusion is that there is an increase in knowledge about breast cancer and BSE skills in the community at Semutan Jatimulyo Dlingo after attending education and training.

Keywords: Breast cancer, Breast Self Examination, Knowledge 


\section{PENDAHULUAN}

Prevalensi penyakit tidak menular di Indonesia semakin meningkat, termasuk penyakit kanker. Data dari Riset Kesehatan Dasar (RISKESDAS) 2018 menunjukkan jumlah penderita kanker semakin meningkat dibanding tahun sebelumnya (RISKESDAS, 2018). Kanker payudara merupakan urutan pertama kanker pada perempuan di dunia (incidence rate 40 per 100.000 perempuan), kasus baru yang ditemukan 30,5\% dengan jumlah kematian 21,5\% per tahun dari seluruh kasus kanker pada perempuan di dunia (Iarc., 2012). Insiden kanker payudara di Indonesia adalah sebesar 26 per 100.000 penduduk. Provinsi Daerah Istimewa Yogyakarta (DIY) memiliki prevalensi tertinggi untuk penyakit kanker payudara yaitu sebesar 2,4\%, diikuti Kalimantan Timur 1,0\%, dan Sumatera Barat 0,9\%. Karakteristik pasien kanker payudara di Indonesia berdasarkan jenis kelamin adalah perempuan sebesar 2,2 per 1000 penduduk dan laki-laki sebesar 0,6 per 1000 penduduk (Badan Penelitian dan Pengembangan Kesehatan, 2013). Dari data Sistim Informasi Rumah Sakit (SIRS) di Indonesia tahun 2010 diketahui bahwa kanker payudara menempati urutan pertama pasien kanker baik rawat inap maupun rawat jalan di seluruh RS Indonesia $(28,7 \%)$. Kanker payudara juga menjadi penyebab kematian kanker terbanyak di Indonesia (Kemenkes, 2015). Jumlah kasus baru penderita kanker payudara di Daerah Istimewa Yogyakarta ditemukan sebanyak 899 kasus dari 4 kabupaten yang dilaporkan, yaitu di Kabupaten Bantul sebanyak 312 kasus (38,01\%), Kabupaten GunungKidul sebanyak 276 kasus $(29,24 \%)$, Kota Yogyakarta sebanyak 273 kasus (28,82\%), dan di Kabupaten Sleman sebanyak 38 kasus (4,01\%) (Dinkes DIY, 2016).

Angka kematian kanker payudara lebih tinggi pada negara berkembang dibandingkan negara maju. Penyebab utama meningkatnya mortalitas kanker di negara berkembang adalah kurangnya program skrining efektif yang dapat mendeteksi keadaan sebelum kanker, maupun mendeteksi kanker pada stadium dini sehingga penanganannya dilakukan sebelum kanker pada stadium lanjut. Selain kurangnya program skrining, juga rendahnya pengetahuan dan kemampuan serta aksesibilitas untuk pengobatan. Oleh karena itu pemeriksaan payudara sendiri secara dini dan edukasi tentang penanganan yang tepat kepada masyarakat sangat dibutuhkan. Pengetahuan masyarakat yang tepat tentang kanker payudara dan upaya deteksi dini masih kurang. Perlu ditingkatkan pemahaman tentang kanker payudara bahwa diagnosis di stadium awal dan dilakukan operasi akan meningkatkan kemungkinan untuk sembuh, dan angka harapan hidup meningkat. Sehingga pada akhirnya bisa menurunkan angka kesakitan dan kematian serta meningkatkan kualitas hidup penderita kanker payudara (Kemenkes, 2015).

Program skrining kanker payudara bisa dilakukan oleh masyarakat dengan periksa payudara sendiri (SADARI) ataupun periksa payudara klinis (SADARNIS) yang dilakukan oleh kader kesehatan ataupun petugas kesehatan sebagai ujung tombak pelayanan kesehatan untuk masyarakat. Penemuan dini dimulai dengan peningkatan kesadaran masyarakat tentang perubahan bentuk atau adanya kelainan di payudara mereka sendiri, dengan cara memasyarakatkan program SADARI bagi semua perempuan dimulai sejak usia subur. Kelainan di payudara $(85 \%)$ pertama kali dikenali oleh penderita bila tidak dilakukan skrining massal. Deteksi dini merupakan upaya pemeriksaan pada masyarakat yang telah merasakan adanya gejala (Kemenkes, 2015). Rendahnya kesadaran masyarakat dalam melakukan deteksi dini kanker payudara dipengaruhi oleh kurangnya pengetahuan tentang kanker payudara, karena kurangnya terpapar dengan 
informasi terkait penyakit tersebut dan manfaat deteksi dini (Sarina dkk., 2020). Penelitian faktor faktor yang mempengaruhi perilaku SADARI pada ibu ibu menunjukkan bahwa dipengaruhi oleh sikap, kurangnya informasi dan aksesbilitas pelayanan kesehatan (Arafah \& Notobroto, 2018). Teknik SADARI sebenarnya mudah dilakukan namun banyak perempuan belum melakukannya karena kurang informasi dan motivasi untuk mendapat informasi mengenai pencegahan dan deteksi dini kanker payudara. Para perempuan baik ibu ibu maupun remaja masih awam dan risih melakukan SADARI sehingga masih sedikit yang melakukan hal tersebut (Pulungan \& Hardy, 2020).

Masyarakat di Dusun Semutan Desa Jatimulyo Kecamatan Dlingo khususnya ibu ibu, masih mempunyai tingkat pengetahuan kanker payudara yang rendah. Pengetahuan tentang deteksi dini kanker payudara dengan metoda SADARI banyak yang belum tahu. Data ini didapat saat awal sebelum kegiatan program dilakukan wawancara dengan ibu ibu dusun tersebut. Berdasarkan hal tersebut maka perlu dilakukan program kegiatan pengabdian masyarakat yang dapat meningkatkan pengetahuan tentang Kanker payudara dan pelatihan untuk dapat melakukan ketrampilan SADARI. Tujuan pengabdian masyarakat ini meningkatkan pengetahuan pengetahuan kanker payudan dan deteksi dini SADARI pada ibu-ibu di Dusun Semutan Jatimulyo Dlingo.

\section{METODE}

Solusi kegiatan yang diprogramkan berdasarkan permasalahan diatas adalah meningkatkan pengetahuan dengan cara pemberian edukasi dan pelatihan SADARI. Program SADARI sebagai upaya deteksi dini dapat menekan kematian kanker payudara sebesar $20 \%$. Karena Pengobatan pada deteksi dini prognosisnya lebih baik, dan angka kesembuhan meningkat, serta harapan hidup lebih tinggi. Tahapan kegiatan yang dilakukan pada pengabdian masyarakat ini:

1. Pemberian edukasi ke masyarakat tentang pengetahuan kanker payudara, yang meliputi materi pengertian kanker payudara, faktor risiko payudara, penyebab kanker payudara, gejala dan tanda kanker payudara, pencegahan dan deteksi dini kanker payudara. Metode yang digunakan adalah dengan penyampaian materi menggunakan media power point, gambar, dan video, dan dilanjutkan diskusi atau tanya jawab.

2. Pelatihan cara deteksi dini kanker payudara dengan cara pemeriksaan payudara sendiri (SADARI). Pelatihan ini meliputi pemberian materi pengertian SADARI, manfaat SADARI, cara melakukan SADARI, kapan SADARI sebaiknya dilakukan, kemudian tanda yang ditemukan, dan kapan harus periksa ke dokter. Metode pelatihan ini dengan penyampaian materi melaui media power point, kemudian memberikan contoh cara melakukan SADARI dengan manikin bagian dada.

3. Kegiatan praktik SADARI yang terbimbing. Peserta dapat melakukan praktik mandiri dengan melakukan SADARI pada manikin, dan didampingi oleh pembimbing. Praktik cara melakukan SADARI meliputi praktik pemeriksaan payudara sendiri dengan berdiri, dan berbaring.

4. Pengukuran peningkatan pengetahuan dilakukan dengan pre-tes dan post-tes yang dilakukan sebelum dan sesudah semua rangkaian kegiatan selesai. Pertanyaan yang diajukan ada 10 butir, yang ditayangkan di power point kemudian peserta menjawabnya. Butir pertanyaan yang diberikan adalah 
dengan jawaban opsi benar atau salah. Ada 10 butir pertanyaan meliputi pengertian kanker, faktor risiko kanker payudara, cara deteksi dini, pencegahan kanker, tanda dan gejala kanker payudara, pengertian SADARI, manfaat SADARI, cara SADARI, dan pemeriksaan lain untuk kanker payudara. Daftar pertanyaan untuk tes pengetahuan bisa dilihat di Tabel 1.

Tabel 1. Daftar Pertanyaan untuk peserta

\begin{tabular}{|l|l|l|}
\hline & Pertanyaan & $\begin{array}{l}\text { Jawaban } \\
\text { B/S }\end{array}$ \\
\hline 1 & Kanker adalah semua tumor jinak maupun ganas & \\
\hline 2 & Tidak menyusui merupakan salah satu factor risiko kanker payudara & \\
\hline 3 & Perokok pasif tidak mempengaruhi kejadian penyakit kanker payudara & \\
\hline 4 & Periksa dada sendiri (SADARI) tidak bisa mendeteksi dini kanker payudara & \\
\hline 5 & Pencegahan kanker dapat dilakukan dengan mengkonsumsi makanan sehat & \\
\hline 6 & $\begin{array}{l}\text { Adanya cairan yang keluar dari putting bukan pada waktu menyusui } \\
\text { merupakan tanda kanker payudara }\end{array}$ & \\
\hline 7 & USG pada payudara dapat digunakan untuk deteksi kanker & \\
\hline 8 & SADARI dapat mendeteksi benjolan pada payudara sedini mungkin & \\
\hline 9 & SADARI dapat mengurangi angka kematian karena kanker payudaa & \\
\hline 10 & Payudara yang tidak simetris kanan dan kiri pasti merupakan Kanker & \\
\hline
\end{tabular}

\section{PELAKSANAAN DAN PEMBAHASAN}

Kegiatan dilaksanakan pada tanggal 18 Januari 2020, di Dusun Semutan Desa Jatimulyo Kecamatan Dlingo mulai pukul 08.00. Kegiatan ini diikuti oleh ibu-ibu dan wanita usia subur di wilayah Dusun Semutan dengan usia berkisar 20-55 tahun, sebanyak 32 peserta. Penyelenggaraan kegiatan ini dilakukan bekerja sama dengan tim bantuan medis mahasiswa Fakultas Kedokteran Universitas Islam Indonesia, dan didukung oleh perangkat desa. Pada kegiatan ini peserta sangat antusias dalam mengikuti acara tersebut, sehingga acara berjalan lancar sampai seluruh rangkaian acara selesai.

Program kegiatan pertama adalah penyampaian materi tentang pengertian kanker payudara, faktor risiko penyakit kanker payudara, penyebab kanker payudara, gejala dan tanda kanker payudara, pencegahan dan deteksi dini kanker payudara. Peserta antusias dan aktif dalam bertanya terhadap hal-hal yang kurang dipahami dalam materi tersebut. Pemberian materi ini diharapkan dapat meningkatkan pengetahuan tentang kanker payudara pada ibu ibu daerah Dusun Semutan Desa Jatimulyo Kecamatan Dlingo. Peningkatan pengetahuan merupakan faktor penting yang berpengaruh terhadap kesadaran masyarakat dalam melakukan pemeriksaan payudara sendiri (SADARI). Penelitian sebelumnya menyatakan bahwa salah satu aspek yang berpengaruh terhadap perilaku SADARI adalah aspek kurangnya pengetahuan tentang kanker payudara karena terbatasnya informasi yang didapat $(\mathrm{p}=0,000)$ (Arafah \& Notobroto, 2018). Penelitian Sarina dkk., (2020) juga menyatakan faktor-faktor yang mempengaruhi kesadaran masyarakat dalam perilaku SADARI adalah tingkat pengetahuan $(\mathrm{p}=0,000)$, dukungan keluarga $(0,001)$ dan keterpaparan informasi $(0,043)$ (Sarina dkk., 2020). Dengan pengetahuan yang meningkat dan informasi yang tepat, diharapkan kesadaran masyarakat untuk melakukan SADARI sebagai upaya deteksi dini semakin meningkat. Hal ini diharapkan dapat menemukan kanker payudara masih dalam stadium awal, dan belum stadium lanjut, sehingga meningkatkan tingkat kesembuhan pada pasien. Foto kegiatan saat penyampaian materi dan Tanya jawab tentang kanker payudara dapat dilihat pada Gambar 1. 


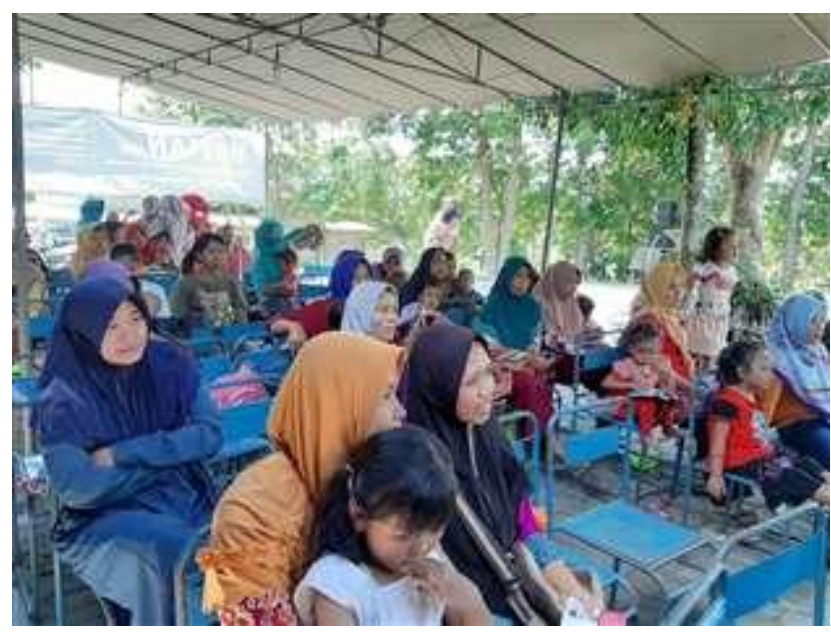

Gambar 1. Kegiatan Penyampaian Materi dan Diskusi

Program kegiatan kedua adalah pelatihan praktik SADARI dengan menggunakan manekin. Pada sesi ini diberikan materi dan praktik tentang pengertian SADARI, manfaat SADARI, cara melakukan SADARI, kapan SADARI sebaiknya dilakukan, kemudian tanda yang ditemukan, dan kapan harus periksa ke dokter. Peserta mengikuti acara ini dengan baik, serta antusias sehingga kegiatan ini berjalan lancar. Pelatihan dengan praktik ini diharapkan dapat membuat peserta lebih paham tentang cara melakukan SADARI. Sehingga ketika akan melakukan praktik sendiri ketrampilan SADARI ini, peserta lebih percaya diri. Foto kegiatan pelatihan praktek SADARI ini dapat dilihat di Gambar 2.

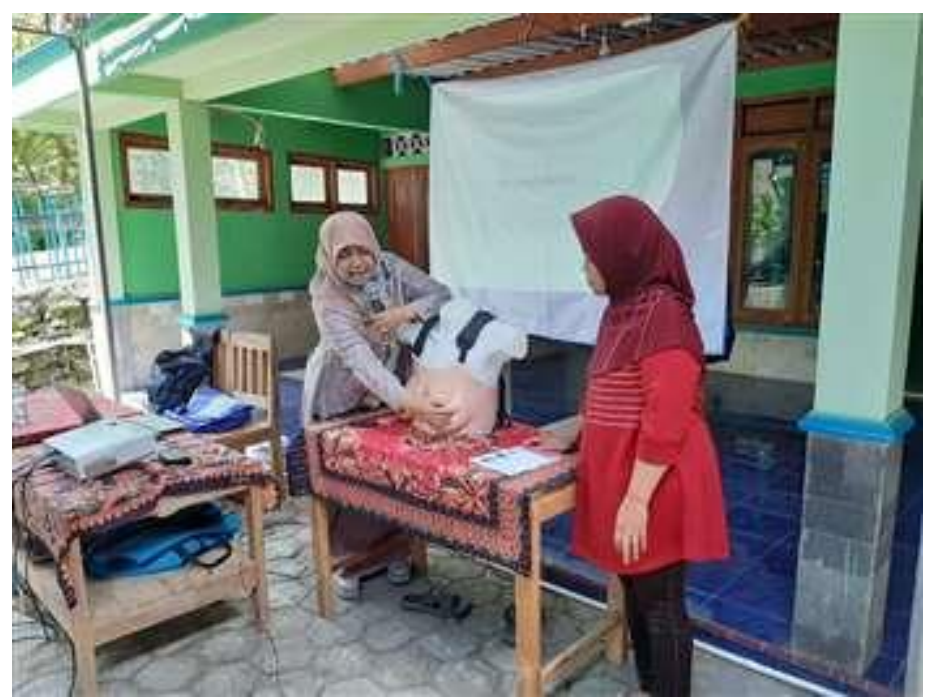

Gambar 2. Pelatihan Pemeriksaan Payudara Sendiri (SADARI)

Program kegiatan yang ketiga adalah peserta melakukan praktik mandiri pemeriksaan SADARI dengan manikin. Beberapa peserta melakukan praktik mandiri ini dengan dibimbing, dan diberitahu kalau ada pemeriksaan yang kurang tepat. Praktek SADARI secara mandiri ini bertujuan agar peserta lebih trampil dalam melakukan SADARI . Pada latihan ini menggunakan manekin payudara yang ada tanda tanda kanker payudaranya sehingga peserta dapat merasakan kondisi abnormal pada saat melakukan SADARI di manekinnya. Pelatihan dengan penggunaan media, dan benda tiruan (manikin payudara) secara bermakna 
meningkatkan pengetahuan $(\mathrm{p}=0,00)$ (Andita, 2018). Praktik ini dilakukan dengan antusias oleh peserta, tetapi karena keterbatasan waktu dan jumlah manikin, maka belum semua peserta dapat mencoba. Gambar praktik mandiri peserta saat melakukan SADARI ke manikin dapat dilihat di Gambar 3.

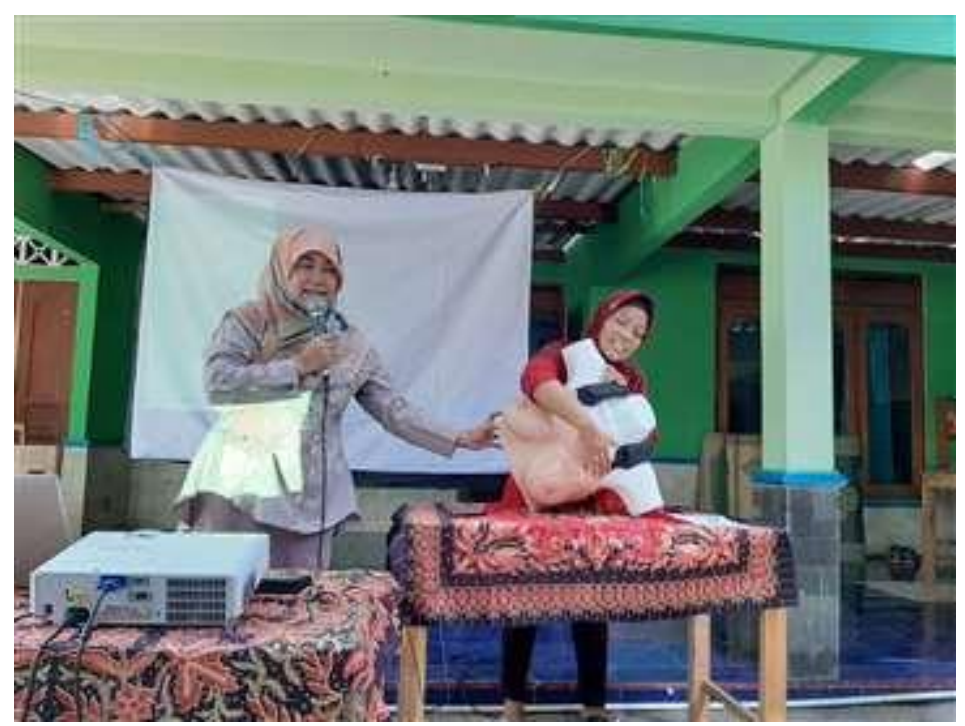

Gambar 3. Peserta melakukan praktik SADARI

Pengetahuan tentang kanker payudara dan ketrampilan SADARI pada ibu ibu di Dusun Semutan Jatimulyo Dlingo ini terlihat adanya peningkatan setelah mengikuti edukasi dan pelatihan, berdasarkan hasil capaian pretest dan post test nya. Pada saat pre test, nilai rata ratanya yang didapatkan adalah 56,875 $\pm 9,310$. Hal ini menggambarkan bahwa tingkat pengetahuan sebelum kegiatan ini masih kurang. Nilai rata rata post test setelah kegiatan selesai adalah $92,813 \pm 6,342$. Analisis menggunakan uji t berpasangan untuk melihat perbedaan rata-rata tes sebelum dan sesudah kegiatan. Terdapat perbedaan bermakna nilai tes sebelum dan sesudah kegiatan dengan $\mathrm{p}=0,00$. Berdasarkan hasil ini dapat dilihat bahwa terdapat peningkatan pengetahuan tentang kanker payudara dan pengetahuan tentang pemeriksaan SADARI pada ibu ibu di Dusun Semutan Jatimulyo Dlingo setelah mengikuti edukasi dan pelatihan. Hal ini memberikan gambaran bahwa kegiatan pemberian edukasi dan pelatihan ini memberikan manfaat yang baik terhadap ibu ibu di Dusun Semutan Jatimulyo Dlingo sehingga diharapkan akan meningkatkan kesadaran perilaku SADARI di kalangan ibu ibu. Perilaku SADARI menurut penelitian sebelumnya dipengaruhi oleh beberapa faktor yaitu tingkat pengetahuan, ketersediaan informasi, dan aksebilitas pelayanan kesehatan (Arafah \& Notobroto, 2018). Terdapat hubungan yang signifikan antara tingkat pengetahuan $(\mathrm{p}=0.001)$, sikap $(\mathrm{p}=0.001)$, dan tingkat pendidikan ( $\mathrm{p}=0.001)$ dengan perilaku deteksi dini SADARI (Fatimah, 2018). Hasil penelitian lain yang sejalan adalah terdapat pengaruh pemberian pendidikan kesehatan terhadap pengetahuan $(p=0,000)$ dan sikap $(\mathrm{p}=0,000)$ wanita usia produktif tentang SADARI dalam upaya deteksi dini kanker payudara (Purba \& Simanjuntak, 2019). Hasil dari kegiatan ini juga sesuai dengan kegiatan edukasi dan pelatihan yang dilakukan di kelurahan Cipayung Depok, yang meningkatkan pengetahun tentang kanker payudara dan SADARI (Pulungan \& Hardy, 2020). Peningkatan perilaku SADARI bisa menjadi deteksi dini terhadap penyakit Kanker Payudara, sehingga dalam stadium awal bisa mendapatkan penangan medis yang tepat. 
Kondisi ini diharapkan dapat meningkatkan harapan kesembuhan dan meningkatkan harapan hidup, secara umum dapat meningkatkan derajat kesehatan di Indonesia.

\section{SIMPULAN}

Terdapat peningkatan pengetahuan tentang kanker payudara dan deteksi dini SADARI pada masyarakat terutama ibu ibu di Dusun Semutan Jatimulyo Dlingo, setelah mengikuti kegiatan pemberian edukasi dan pelatihan serta praktik SADARI. Hal ini menunjukkan bahwa edukasi dan pelatihan merupakan metoda efektif dalam meningkatkan pengetahuan masyarakat. Meningkatnya pengetahuan masyarakat tentang kanker payudara dan deteksi dini SADARI dapat meningkatkan harapan kesembuhan dan meningkatkan harapan hidup, juga meningkatkan derajat kesehatan di Indonesia.

\section{UCAPAN TERIMA KASIH}

Kami mengucapkan banyak terima kasih kepada tim bantuan medis mahasiswa Fakultas Kedokteran Universitas Islam Indonesia yang telah menyelenggarakan kegiatan ini. Terima kasih juga kepada perangkat Dusun Semutan Jatimulyo Dlingo dan Ibu ibu kader kesehatan, yang membantu dalam penyelenggaraan kegiatan pengabdian masyarakat ini.

\section{DAFTAR PUSTAKA}

Andita, U. (2018). Pengaruh Pendidikan Kesehatan Sadari Dengan Media Slide Dan Benda Tiruan Terhadap Perubahan Pengetahuan Wus. Jurnal Promkes, 4(2), 177. https://doi.org/10.20473/jpk.v4.i2.2016.177187

Arafah, A. B. R., \& Notobroto, H. B. (2018). Faktor Yang Berhubungan Dengan Perilaku Ibu Rumah Tangga Melakukan Pemeriksaan Payudara Sendiri (Sadari). The Indonesian Journal of Public Health, 12(2), 143. https://doi.org/10.20473/ijph.v12i2.2017.143-153

Badan Penelitian dan Pengembangan Kesehatan. (2013). Riset Kesehatan Dasar 2013. Riset Kesehatan Dasar 2013.

Dinkes DIY. (2016). 1 Profil Kesehatan DIY 2016. Dinas Kesehatan DIY, 180.

Fatimah, H. R. (2018). Faktor-faktor yang Mempengaruhi Perilaku Deteksi Dini Kanker Payudara dengan SADARI pada Wanita di Kecamatan Tegalrejo Kota Yogyakarta. Jurnal Psikologi Terapan Dan Pendidikan, 99.

Iarc., I. A. for R. on C. W. H. O. (2012). Globocan 2012: Estimated Cancer Incidence, Mortality and Prevalence Worldwide in 2012. Globocan. https://doi.org/10.1002/ijc.27711

Kemenkes. (2015). Permenkes RI no 34 tahun 2015, tentang Penganggulangan Kanker Payudara dan Kanker Leher Rahim. In Permenkes RI .

Pulungan, R. M., \& Hardy, F. R. (2020). Edukasi Sadari (Periksa Payudara Sendiri) untuk Deteksi Dini Kanker Payudara Di Kelurahan Cipayung Kota Depok. Diseminasi: Jurnal Pengabdian Kepada Masyarakat. https://doi.org/10.33830/diseminasiabdimas.v2i1.756

Purba, A. E. T., \& Simanjuntak, E. H. (2019). Efektivitas Pendidikan Kesehatan Sadari terhadap Peningkatan Pengetahuan dan Sikap Wus tentang Deteksi Dini Kanker Payudara. Jurnal Bidan Komunitas, 2(3), 160. https://doi.org/10.33085/jbk.v2i3.4476

Riskesdas. (2018). Riset Kesehatan Dasar 2018. In Kementrian Kesehatan Republik Indonesia.

Sarina, Thaha, R. M., \& Sudirman Natsir. (2020). Faktor yang Berhubungan dengan Perilaku SADARI sebagai Deteksi Dini Kanker Payudara pada Mahasiswi FKM UNHAS. Hasanuddin Journal of Public Health, 1(1), 61-70. http://journal.unhas.ac.id/index.php/hjph/article/view/9510 